\title{
Antibacterial Activity of Water Extract From Some Folk Medicine at Bidoup-Nuiba National Park, Lam Dong, Vietnam
}

\author{
Pham Minh Nhut ${ }^{12^{*}}$, Dang Thi Phuong Thao ${ }^{1}$ \\ ${ }^{1}$ Department of Molecular and Environmental Biotechnology, Faculty of Biology, University of Science, Vietnam National \\ University, Ho Chi Minh City, Vietnam \\ ${ }^{2}$ Hutech Institute of Applied Science, Ho Chi Minh University of Technology, Vietnam
}

*Address for Correspondence: Dr. Pham Minh Nhut, Department of Molecular and Environmental Biotechnology, Faculty of Biology, University of Science, Vietnam National University Ho Chi Minh City, Vietnam227 Nguyen Van Cu Street, District 5, Ho Chi Minh City, Vietnam

E-mail: dtpthao@hcmus.edu.vn

Received: 05 Jul 2019/ Revised: 16 Sep 2019/ Accepted: 22 Dec 2019

\begin{abstract}
Background: Folk medicinal plants were used to treat some common diseases such as diarrhea, wound healing by ethnic minorities at Bidoup-Nui Ba National Park, Lam Dong province, Vietnam. However, the usage of medicinal plants was mainly based on experience and there was no scientific basis to prove the biological activity of medicinal plants. This study aims to evaluate the biological activity of some folk medicinal plants used by ethnic minorities.

Methods: In this study, 9 samples of folk medicinal plants that ethnic minorities used to treat diarrhea at Bidoup-Nui Ba National Park, Lam Dong province were water extracted and evaluated the antibacterial activity against 16 indicators bacterial sp. by well diffusion agar. The water extracts were chemically tested for the presence of different constituents, including carbohydrates, alkaloids, saponins, cardiac glycosides, anthraquinone glycosides, flavonoids, phenolic compounds, tannin, steroids and amino acids by using standard methods.

Results: The results showed that water extract from Medinilla septentrionalis had the highest antibacterial activity (against $16 / 16$ indicator bacteria) with inhibition diameter zone from $9.3 \mathrm{~mm}-11.0 \mathrm{~mm}, 4 / 9$ water extracts had weak activity and 4/9 extracts had no antibacterial activity. The preliminary phytochemical screening of the water extracts showed the presence of flavonoids and tannins.

Conclusion: Although the medicinal plants have been used widely by ethnic people in the type of water extract, this study showed that water is not a good solvent for extracting biological compounds from the medicinal plants. Further studies on theses plants should be carried out either for evaluating their antibacterial activity or investigating their antidiarrheal activity.
\end{abstract}

Key-words: Antibacterial activity, Antidiarrhea, Bidoup-Nui Ba, Folk medicine, Water extract

\section{INTRODUCTION}

Vietnam is a tropical country with an abundant and diverse medicinal plant. According to recent statistics, the flora of Vietnam has over 10,000 species. Vietnam has about 3,200 species of herbs. Although the sources of medicinal plants in our country are abundant, the use and exploitation are limited, especially the folk medicinal plants and indigenous knowledge.

\section{How to cite this article}

Nhut PM and Thao DTP. Antibacterial Activity of Water Extract From Some Folk Medicine at Bidoup-Nuiba National Park, Lam Dong, Vietnam. SSR Inst. Int. J. Life Sci., 2020; 6(1): 2449-2454.

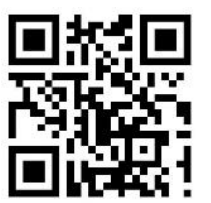

Access this article online https://iijls.com/
Folk medicinal plants are widely used by the ethnic people in the treatment of diseases by cooked with water until close to dry and then thoroughly drained for use ${ }^{[1-3]}$.

Bidoup-Nui Ba National Park is a large biodiversity center of Vietnam with 461 species of medicinal plants. K'Ho people, the main ethnic minority live here, often use plants, leaves to treat some diseases such as diarrhea, ulcers, abrasions, etc ${ }^{[4]}$. However, there have been few studies on folk medicinal plants at Bidoup-Nui Ba National.

Diarrhea is caused by many reasons including bacterial infections such as Salmonella enteritidis, S. typhi, Shigella flexneri, E. coli, Vibrio cholerae, Clostridium difficile or chemicals such as castor oil or magnesium sulfate ${ }^{[5-7]}$. 
To treat diarrhea, some methods have been used such as oral rehydration therapy, antibiotics and gut motility suppressing agents or pharmacological agents, etc. The usage is depending on the cause and the severity of the disease [8-10]. However, medicine like loperamide, diphenoxylate, racecadotril might cause undesirable side effects as vomit, dry mouth, abdominal discomfort, constipation and headache [11-13]. Recently, herbal remedies are great applications of interest. Most of medicinal plants have alkaloid, steroid, tannin and phenol which are stored in some different part of the plants ${ }^{[14]}$. These metabolites are well known as antibacterial substances, which prevent bacterial infection into the plants. Although the antibacterial mechanism still was not fully reported, it is known that the metabolite inhibit bacterial DNA/RNA synthesis, interfere bacterial metabolism, and destroy bacterial cell membrane ${ }^{[15,16]}$. In this study, we evaluated the antimicrobial activity of the folk medicinal plants against some bacteria that cause diarrhea.

\section{MATERIALS AND METHODS}

Folk medicinal plants and extraction- Medicinal plants (Elephantopus mollis Kunth, Lantana camara L., Euodia lepta (Spreng.) Merr., Acorus tatarinowii Schott., Calamus sp., Medinilla septentrionalis (W.W.Sm) M.P. Nayar., Polygala paniculata L., Podocarpus imbricatus Blume., Eupatorium odoratum L.) (Table 1) were collected from Bidoup-NuiBa National Park, Lam Dong province, Vietnam and identified at Department of Ecology and Evolutionary Biology, Faculty of Biology, University of Science, VNU-HCMC from August 2016 to September 2017. These samples were extracted according to Akinyemi et al. [4] with modification. Samples were dried, powdered and extracted with water by immersion method $[1: 10(\mathrm{w} / \mathrm{v})]$ at room temperature for 4 hours. The extracts were filtered and evaporated at $40^{\circ} \mathrm{C}$ using a rotary evaporator to constant weight. The extracts were then dissolved in sterile distilled water and stored in a sterilized bottle in $4^{\circ} \mathrm{C}$ temp.

Table 1: Medicinal plants from Bidoup-Nui Ba National Park, Lam Dong province, Vietnam

\begin{tabular}{lll}
\hline Plants name & Vietnamese name & Used plant parts \\
\hline Elephantopus mollis Kunth & Chan voi mem & Bud \\
Lantana camara L. & Bong oi & Bud \\
Euodia lepta (Spreng.) Merr. & Ba chạc & Bud and leaf \\
Acorus tatarinowii Schott & Thachxuongbo & Base \\
Calamus sp. & May rung & Bud \\
Medinilla septentrionalis (W.W.Sm) M.P.Nayar & Xidranguom & Bud and leaf \\
Polygala paniculata L. & Kichnhuthom & Whole tree \\
Podocarpus imbricatus Blume & Bach tung & Stem core, leaf \\
Eupatorium odoratum L. & Co hoi & Root \\
\hline
\end{tabular}

Indicator bacterial species- Indicator bacteria were provided by the Department of Molecular and Environmental Biotechnology, Faculty of Biology, University of Science, VNU including 3 strains of Shigella sp. (S. sonnei, S. flexneri, and $S$. boydii), 4 strains of Salmonella sp. (S. typhimurium, S. typhii, S. dublin, S. enteritidis), 3 strains of $E$. coli (Enterotoxigenic E. coli (ETEC), E. coli 0157:H7, E. coli), 3 strains of Vibrio sp. (V. cholerae, V. parahaemolyticus), 2 strains of Listeria sp. ( $L$. monocytogenes, L. innocua) and S. aureus.
Antibacterial activity- Antibacterial activity of 9 water extracts was evaluated by well diffusion agar method $[17,18]$. Indicator bacterial sp. was enriched in the suitable medium at temperature $37^{\circ} \mathrm{C}$ at 24 hours. $100 \mu \mathrm{l}$ of diluted bacteria $\left(10^{6} \mathrm{cfu} / \mathrm{ml}^{-1}\right)$ solution was spread on agar medium until drying. Then, wells (6 $\mathrm{mm}$ diameter) were made in each plate by using sterile metal cylinders. $100 \mu \mathrm{l}$ of every water extract $\left(100 \mathrm{mg} / \mathrm{ml}^{-1}\right)$ were dropped into the wells. Sterile distilled water was used as a control. Plates were incubated at $37.0 \pm 0.1^{\circ} \mathrm{C}$ at 24 hours. The diameter of the inhibition zone $(\mathrm{mm})$ was 
measured. Each experiment was triplicated and collected data were subjected to statistical analysis.

Preliminary phytochemical analysis- Total 9 water extracts were identified ${ }^{[17]}$ the presence of constituents, including carbohydrate (Molisch, Fehling and Barfoed test), alkaloid (Mayer, Dragendorff, Hager and Wagner test), saponin (foam test), cardiac glycoside (Legal and Keller-Killiani test), anthraquinone glycoside (Bontrager test), flavonoid (alkaline and ferric chloride test), tannin (ferric chloride and lead acetate test), steroid (Salkowski and Libermann Burchard test), amino acid (ninhydrin test).

Statistical Analysis- Statistical analysis values were expressed as meantstandard deviation. Mean values

Table 2: The extractive efficiency of water extract were evaluated by Analysis of Variance. Duncan test was used to determine the statistical significance $(P<0.05)$.

\section{RESULTS}

Identification of the extractive efficiency of water extracts- Water is a solvent that used to extract the compound from medicinal plants by $\mathrm{K}^{\prime} \mathrm{Ho}$ people at Bidoup-Nui Ba National Park. We, therefore utilized it for preparation of the plant extracts. The extractive efficiency of 9 medicinal plants with water was a statistically significant difference $(p<0.05)$ (Table 2$)$. The extraction efficiency of $E$. lepta was highest (29.52\%), while the extraction efficiency from $E$. mollis, $P$. imbricatus, L. camara was low (<20\%).
Medicinal plants

L. camara

A. tatarinowii

$$
\text { E. lepta }
$$

Calamus sp.

M. septentrionalis

P. paniculata

E. mollis

P. imbricatus

E. odoratum

\section{Extractive efficiency of water extract (\%)}

$12.36 \pm 0.43^{e f}$

$25.74 \pm 0.52^{a b}$

$29.52 \pm 1.04^{a}$

$21.69 \pm 0.44^{d}$

$20.18 \pm 1.19^{\text {de }}$

$20.53 \pm 1.09^{d}$

$15.15 \pm 0.46^{e f}$

$11.99 \pm 0.43^{f}$

$25.46 \pm 2.04^{b c}$
Antibacterial activity of water extracts- The results of the antimicrobial activity of water extracts against indicator bacteria showed that 4/9 plant extracts did not inhibit indicator bacteria, while another 5/9 water extracts showed different antibacterial activity (Table 3). In particular, $M$. septentrionalis water extract showed the strongest antibacterial activity (inhibition to 16/16 indicator bacteria), $P$. paniculata, $P$. imbricatus, $E$. odoratum, and $E$. mollis water extract inhibited 6/16, $2 / 16,1 / 16$ and $1 / 16$ indicator bacteria at $100 \mathrm{mg} / \mathrm{ml}$ concentration, respectively.

Table 3: Antibacterial inhibition zone of water extracts against indicator bacteria ( $\mathrm{mm})$

\begin{tabular}{lccccccccc}
\hline Bacterial sp. & LC & AT & EL & CA & MS & PP & EM & PI & EO \\
\hline E. coli 0157:H7 & NA & NA & NA & NA & $11.00 \pm 0.50$ & NA & NA & NA & NA \\
E. coli & NA & NA & NA & NA & $10.17 \pm 1.15$ & $8.17 \pm 0.29$ & NA & NA & NA \\
ETEC & NA & NA & NA & NA & $9.83 \pm 0.29$ & $8.83 \pm 0.39$ & NA & NA & NA
\end{tabular}




\begin{tabular}{|c|c|c|c|c|c|c|c|c|c|}
\hline L. innocua & NA & NA & NA & NA & $10.17 \pm 0.58$ & NA & NA & NA & NA \\
\hline L. monocytogenes & NA & NA & NA & NA & $12.83 \pm 0.29$ & $10.00 \pm 0.00$ & NA & NA & NA \\
\hline S. dublin & NA & NA & NA & NA & $11.00 \pm 0.50$ & NA & NA & NA & NA \\
\hline S. enteritidis & NA & NA & NA & NA & $10.75 \pm 0.35$ & NA & NA & NA & NA \\
\hline S. typhii & NA & NA & NA & NA & $9.67 \pm 0.29$ & $9.00 \pm 1.00$ & NA & $9.83 \pm 0.29$ & NA \\
\hline S. typhimurium & NA & NA & NA & NA & $10.83 \pm 0.58$ & NA & NA & NA & NA \\
\hline S. boydii & NA & NA & NA & NA & $11.75 \pm 0.40$ & NA & NA & NA & $13.17 \pm 0.29$ \\
\hline S. flexneri & NA & NA & NA & NA & $9.83 \pm 0.29$ & NA & $12.17 \pm 0.29$ & NA & NA \\
\hline S. sonnei & NA & NA & NA & NA & $9.33 \pm 0.60$ & NA & NA & $11.5 \pm 0.00$ & NA \\
\hline V. cholerae & NA & NA & NA & NA & $10.00 \pm 1.00$ & NA & NA & NA & NA \\
\hline V. parahaemolyticus & NA & NA & NA & NA & $9.83 \pm 0.76$ & $8.33 \pm 0.59$ & NA & NA & NA \\
\hline S. aureus & NA & NA & NA & NA & $9.83 \pm 0.29$ & NA & NA & $10.00 \pm 0.00$ & $9.5 \pm 0.00$ \\
\hline E. feacalis & NA & NA & NA & NA & $9.50 \pm 0.50$ & $11.50 \pm 1.50$ & NA & NA & NA \\
\hline
\end{tabular}

LC: Lantana camara; MS: Medinilla septentrionalis; PP: Polygala paniculata; AT: Acorustatarinowii; EM: Elephantopusmollis; PI: Podocarpusimbricatus; EL: Euodialepta; EO: Eupatorium odoratum; CA: Calamus sp.

Phytochemical identification of the water extracts- The results of the chemical composition of water extracts from 9 medicinal plants showed that carbohydrates

Table 4: Phytochemical constituents of water extracts presented at all water extracts. In addition, there was the presence of several biologically active compounds, including alkaloids, tannins, and flavonoids (Table 4).

\begin{tabular}{|c|c|c|c|c|c|c|c|c|c|c|}
\hline Constituents & Test & LC & AT & EL & CA & MS & PP & EM & $\mathbf{P I}$ & EO \\
\hline \multirow{4}{*}{ Carbohydrate } & Molisch & + & + & + & + & + & + & + & + & + \\
\hline & Fehling & + & + & + & + & + & + & + & + & + \\
\hline & Barfoed & + & + & + & + & + & + & + & + & + \\
\hline & Mayer & + & - & + & - & - & + & - & - & - \\
\hline \multirow{3}{*}{ Alkaloid } & Dragendorff & + & - & + & - & - & + & - & - & - \\
\hline & Hager & + & - & + & - & - & + & - & - & - \\
\hline & Wagner & + & - & + & - & - & + & - & - & - \\
\hline Saponin & Foam & + & + & + & + & + & + & + & + & + \\
\hline \multirow{2}{*}{ Cardiace glycoside } & Legal & + & + & + & + & + & + & + & + & + \\
\hline & Keller-Killiani & + & + & + & + & + & + & + & + & + \\
\hline $\begin{array}{l}\text { Anthraquinone } \\
\text { glycoside }\end{array}$ & Borntrager & - & - & - & - & + & + & + & + & + \\
\hline \multirow{2}{*}{ Flavonoid } & Alkaline & + & + & + & + & + & + & + & + & + \\
\hline & Ferric chloride & + & + & + & + & + & + & + & + & + \\
\hline \multirow{2}{*}{ Tannin } & Ferric chloride & + & + & + & + & + & + & + & + & + \\
\hline & Lead acetate & + & + & + & + & + & + & + & + & + \\
\hline
\end{tabular}




\begin{tabular}{ccccccccc}
\hline Steroid & Salkowski & + & + & + & + & + & + & + \\
& Libermann-Burchard & + & + & + & + & + & + \\
+ & + \\
Amino acid & Ninhydrin & - & - & - & - & - & - & - \\
\hline
\end{tabular}

(+): positive; (-): negative

LC: Lantana camara; MS: Medinilla septentrionalis; PP: Polygala paniculata; AT: Acorustatarinowii; EM: Elephantopusmollis; PI: Podocarpusimbricatus; EL: Euodialepta; EO: Eupatorium odoratum; CA: Calamus sp.

\section{DISCUSSION}

Understanding the effectiveness of traditional plants, which used by ethnic people are important in order to sustainable mining folk medicinal plants and develop the usage, this study aimed to evaluate the antibacterial effectiveness of folk medicinal water extract that used by the K'Ho ethnic group in the treatment of some common diseases including diarrhea.

To elucidate the antibacterial activity of the plants and the indicator bacterial sp. belonged to the gastroenterogenic bacteria including $S$. typhii caused typhoid; S. enteritidis, S. flexneri and E. coli caused diarrhea; S. sonnei, S. boydii caused dysentery; Vibrio sp. caused many dangerous intestinal diseases such as cholera $(V \text {. cholerae })^{[17,18]}$. The results showed that the antimicrobial activity of water extracts from 9 folk medicinal plants was very low, except $M$. Septentrionalis water extract had high antibacterial activity. This study showed that water was not a good solvent to extract antimicrobial compounds for those plants in this study. However, in the daily file, ethnic people, mostly boiled the medicinal plants in water and used to treat diarrhea. Our study results suggested that the usage even based on people experiences but may not high efficiency in treatment as the antibacterial activity is low in $8 / 9$ plants except $M$. septentrionalis.

Besides, our results of the preliminary phytochemical screening also provided the scientific evidences that the plants contain some well known antibacterial compounds such as flavonoid phenolic compound. The plants also contain some compounds that can precipitate protein, which functions on the electrolyte and reduce small intestine transit and intestinal secretion such as tannin and flavonoid ${ }^{[19,20]}$. Taken together, the study suggested that the folk medicinal plants play antidiarrheal activity via their antibacterial potential and their metabolite activity on electrolyte, intestine. However, the traditional usages should be improved by using different solvent for plant extracts.

\section{CONCLUSIONS}

In 9 folk medicinal plant samples at Bidoup-Nui Ba National Park, only 5/9 water extracts had antibacterial activity against diarrhea relating indicator bacteria and M. septentrionalis water extract had the strongest antibacterial activity (19/19 indicator bacteria) at 100 $\mathrm{mg} / \mathrm{ml}$ concentration.

This result showed that water is not a good solvent for extracting biological compounds from all medicinal plants; therefore, it is important to investigate before using water to extract from medicinal plants.

\section{ACKNOWLEDGMENTS}

We thank Vietnam National University in Ho Chi Minh City for funding this study. We thank Directors of BidoupNui Ba National Park, Lam Dong Province for facilitating to collect samples. We thank BSc. Pham Thi Thao, Lam Pham Hue Tam at Ho Chi Minh City University of Technology has supported the experiment.

\section{CONTRIBUTION OF AUTHORS}

Research concept- Dr. Dang Thi Phuong Thao, Pham Minh Nhut

Research design- Dr. Dang Thi Phuong Thao, Pham Minh Nhut

Supervision- Dr. Dang Thi Phuong Thao

Materials- Dr. Dang Thi Phuong Thao, Pham Minh Nhut

Data collection- Dr. Dang Thi Phuong Thao, Pham Minh Nhut

Data analysis and Interpretation- Dr. Dang Thi Phuong Thao, Pham Minh Nhut

Literature search- Dr. Dang Thi Phuong Thao, Pham Minh Nhut

Writing article- Dr. Dang Thi Phuong Thao, Pham Minh Nhut

Critical review- Dr. Dang Thi Phuong Thao

Article editing- Dr. Dang Thi Phuong Thao, Pham Minh Nhut

Final approval- Dr. Dang Thi Phuong Thao 


\section{REFERENCES}

[1] Ban PH, Hai NT. Traditional medicinal plants from Thai people in Quy Hop and Que Phong Nghe An, Vietnam. Conference in Ecology and Bio-Resource, 2013; 939-44.

[2] Huong LTT, Phuong ND, Tuoi HT, An DT. Nguyen Trung Thanh and Nguyen Nghia Thin. Investigation of medicinal plants and their effectiveness as fork medicine in San Diu people, Thai Nguyen, Vietnam. J. Natural Sci. Technol., 2014; 30(3): 7-16.

[3] Huong LTT, Quan HV, Ve DV, Thanh NT. Investigation of medicinal plants and their usage as fork medicine in Tay people, Van Quan, Lang Son, Vietnam. J. Natural Sci. Technol., 2015; 31 (4): 45-55.

[4] Akinyemi KO, Oluwa OK, Omomigbehin EO. Antimicrobial activity of crude extracts of three medicinal plants used in South-West Nigerian folk medicine on some food borne bacterial pathogens. Afr. J. Trad. CAM, 2006; 3(4): 13-22.

[5] Bhattacharjee I, Chatterjee SK, Ghosh A, Chandra G. Antibacterial activities of some plant extract used in Indian traditional folk medicine. Asian. Pac. J. Trop. Biomed., 2011; S165-S69.

[6] Gobalakrishnan R, Kulandaivelu M, Bhuvaneswari R, Kandavel D, Kannan L. Screening of wild plant species for antibacterial activity and phytochemical analysis of Tragiainvolucrata L. J Pharm. Anal., 2013; 3: 46065.

[7] Jayaveera KN, Yoganandham RK, Govindarajula Y, Kumanan R. Phytochemical screenings, antibacterial activity and physical chemical constants of ethanolic extract of Euphorbia thymifolia Linn. Int. J. Pharm. Pharm. Sci., 2010; 2: 81-82.

[8] Mabeku LBK, Roger KJ, Louis OSJ. Screening of some plants used in the Cameroonian folk medicine for the treatment of infectious diseases. Int. J. Biol., 2011; 3: 13-21.

[9] Milosevic T, Solujic S, Sukdolak S. In vitro study of ethanolic extract of Hypericum perforatum $\mathrm{L}$. on growth and sporulation of some bacteria and fungi. Turk J. Biol., 2007; 31: 237-41.

[10]Sen A, Batra A. Evaluation of antibacterial activity of different solvent extracts of medical plants. Melia azedarach L. Int. J. Curr. Pharm. Res., 2012; 4: 67-73.
[11]Silva NNC, Fernandes Junior A. Biological properties of medicinal plants: a review of their antimicrobial activity. JVATiTD, 2010; 16:402-413.

[12]Palombo EA. Phytochemicals from traditional medicinal plants used in the treatment of diarrhoea: Modes of action and effects on intestinal function. Phyther. Res., 2006; 20: 717-24.

[13]Adeshina I, Jenyo-Oni A, Emikpe BO, Ajani EK, Effect of Solvents on Phytoconstituents and Antimicrobial Activities of Ocimum gratissimum and Eugenia caryophyllata extracts on Listeria monocytogenes. Acta Veterinaria Eurasia. 2018; 44: $31-8$.

[14]Admad AR, Waris R. Inhobitory Potential of Poligalapaniculata L. Against $\alpha$-glucosidase. Int. J. Pharm. Tech. Res., 2016; 9(12):531 - 35.

[15]Afagnini AD, Nyegue MA, Foe CFN, Ndam YN, Njayou FN, Fonkoua MC, Etoa FX, Antidiarrheal Activity of Dissotis multiflora (Sm) Triana (Melastomataceae) Leaf Extract in Wistar Rats and Subacute Toxicity Evaluation. Evidence-Based Complementary and Alternative Medicine. 2017; 234-43.

[16]Ciocan ID, Bara II, Plant products as antimicrobial agents. Scientific Annals of the University, Alexandru Ioan Cuza Section of Genetics and Molecular Biology. 2007; 8: $151-58$.

[17]Santos SAO, Martins C, Pereira C, Silvestre AJD, Rocha SM. Current Challenges and Perspectives for the Use of Aqueous Plant Extracts in the Management of Bacterial Infections: The Case-Study of Salmonella enterica Serovar. Int. J. Molecular Sci., 2019; 20 (940), 124- 41.

[18]Silva NCC, Fernandes Junior A. Biological properties of medical plants: a review of their antimicrobial activity. The Journal of Venomous Animals and Toxin including Tropical Dis., 2010; 16(3), 402-13.

[19]Rajeswari K, Kumar AR, Rathinam KMS. Phytochemical and anti diarrhoeal activity of Hippocratea Africana roots. Indian J. Res. Pharm. Biotech., 2014; 2(4): 1357-59.

[20]Sai BN, Chand CVG, Krishna GR, Kumar AR, Reddy AJR, Vallabh V. Phytochemical and anti-diarrhoeal activity of extract of Morinda citrifolia. Int. J. Pharm. Chem. Biol. Sci., 2015; 5(1): 138-40.

\section{Open Access Policy:}

Authors/Contributors are responsible for originality, contents, correct references, and ethical issues. SSR-IIJLS publishes all articles under Creative Commons Attribution- Non-Commercial 4.0 International License (CC BY-NC). https://creativecommons.org/licenses/by-nc/4.0/legalcode (c) (i) (8) 